\title{
Correction to: Roles of mortar volume in porosity, permeability and strength of pervious concrete
}

\author{
Leo Gu Li ${ }^{1,2^{*}}$, Jia-Jian Feng ${ }^{3}$, Bo-Feng Xiao ${ }^{1}$, Shao-Hua $\mathrm{Chu}^{4}$ and Albert Kwok Hung Kwan ${ }^{2}$
}

\section{Correction to: J Infrastruct Preserv Resil 2, 19 (2021) https://doi.org/10.1186/s43065-021-00033-2}

Following publication of the original article [1], it was reported that there was an error in Fig. 6. The y-axis was incorrectly labelled 'Interconnected porosity (\%)' instead of 'Open porosity (\%)'. The correct figure is provided in this Correction article and the original article has been updated.

\section{Author details}

${ }^{1}$ Guangdong University of Technology, Guangzhou, China. ${ }^{2}$ The University of Hong Kong, Hong Kong, China. ${ }^{3} \mathrm{CIFI}$ Group, Shanghai, China. ${ }^{4}$ The Chinese University of Hong Kong, Hong Kong, China.

Published online: 03 August 2021

\section{Reference}

1. Li LG, Feng JJ, Xiao BF, Chu SH, Kwan AKH (2021) Roles of mortar volume in porosity, permeability and strength of pervious concrete. J Infrastruct Preserv Resil 2:19. https://doi.org/10.1186/s43065-021-00033-2

* Correspondence: ligu@gdut.edu.cn

'Guangdong University of Technology, Guangzhou, China

${ }^{2}$ The University of Hong Kong, Hong Kong, China

Full list of author information is available at the end of the article

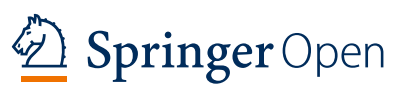

(c) The Author(s). 2021 Open Access This article is licensed under a Creative Commons Attribution 4.0 International License, which permits use, sharing, adaptation, distribution and reproduction in any medium or format, as long as you give appropriate credit to the original author(s) and the source, provide a link to the Creative Commons licence, and indicate if changes were made. The images or other third party material in this article are included in the article's Creative Commons licence, unless indicated otherwise in a credit line to the material. If material is not included in the article's Creative Commons licence and your intended use is not permitted by statutory regulation or exceeds the permitted use, you will need to obtain permission directly from the copyright holder. To view a copy of this licence, visit http://creativecommons.org/licenses/by/4.0/. 


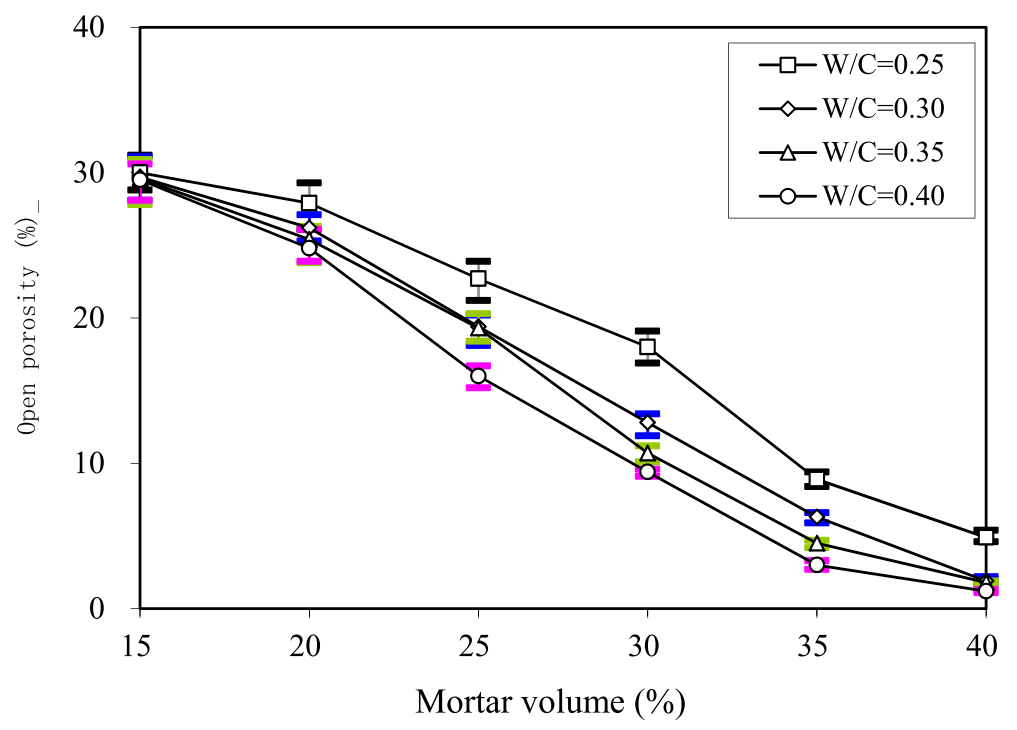

Fig. 6 Open porosity versus mortar volume for different W/C ratios 